\title{
THE ECONOMIC ANALYSIS OF AIR POLLUTION MITIGATION MEASURES IN SMALLER PORTS
}

\author{
Marina Zanne, ${ }^{1}$ Elen TwrdY ${ }^{2}$ \\ University of Ljubljana (Slovenia)
}

\begin{abstract}
Huge quantities of cargo are handled, stored and processed annually in the world's ports. It is clear that ports play an important role in the development of the economy and society around the world. However, port operations on both the sea and the land side are also having negative effects, which in today's environmentally sensitive society are becoming an increasing problem. Therefore, port authorities and operators need to look for solutions to reduce these negative effects, while maintaining or even increasing a port's competitiveness. This is not an easy task, as ports differ from each other in many ways, and the ability to implement certain solutions, and the effectiveness of selected solutions, can vary significantly between them. In this article, the authors focus on the problem of air emissions from port operations. They address all the sources of port air emissions, and verify the effectiveness of selected air emission mitigation measures in smaller cargo ports. Efficacy examples of selected measures are shown in the case of the Port of Koper, the only Slovenian cargo port in the north Adriatic, which handled almost 23 million tonnes of cargo in 2019.

KEY WORDS: port emissions, air emissions, mitigation measures, smaller port, cost benefit analysis.
\end{abstract}

JEL CODES: R42, R11, O18.

DOI: http://dx.doi.org/10.15181/rfds.v33i1.2206

\section{Introduction}

The importance of ports to the development of societies and economies around the world is undeniable; around 11 billion tonnes of cargo are transported by sea (UNCTAD, 2019), and ports ensure that this cargo is shipped quickly, stored safely, and, if necessary, processed. In addition to directly supporting international trade, ports also create many jobs: around 1.5 million people are employed in European ports alone, and about as many in ancillary activities (EC, 2015).

Many operations, involving a lot of mechanisation, take place in ports, which causes negative effects that are manifested as emissions and dust, noise, land usage and visual deterioration, congestion on surrounding roads, etc. (Merk, 2013). This is especially problematic if the port is located near urban areas. Because of these negative externalities, the positive perception of ports as being generators of socio-economic growth is somewhat lost, especially in near-port communities (Merk, 2013; Zhao et al., 2017). Therefore, ports must strive to mitigate these negative effects, while ensuring economic efficiency and competitiveness.

In this article, the authors present the sources of negative environmental effects in ports, and focus on air quality degradation resulting from port activities. By using a case study analysis, they check how these problems are addressed in selected smaller and financially weaker cargo ports in Europe.

\footnotetext{
Marina Zanne - University of Ljubljana, Faculty of Maritime Studies and Transport Scientific interests: Transport economics

E-mail: Marina.Zanne@fpp.uni-lj.si

2 Elen Twrdy - University of Ljubljana, Faculty of Maritime Studies and Transport Scientific interests: Transport technology

E-mail: Elen.Twrdy@fpp.uni-lj.si
} 


\section{Air pollution in ports}

Ports around the world have evolved in diverse ways, and have acquired different global importance over time, depending on many factors, such as (Tongzon, 2002; Wu, 2011): the location of the port, economic activity in the port's hinterland and its accessibility, the port's infrastructure and equipment, the port's efficiency, sailing frequency, port charges and the costs of auxiliary services, the reputation of the port, etc. Nevertheless, whether small or large, ports can certainly be considered specific socio-technical organisations that have become crucial logistical links in the production, distribution and consumption chains of economies worldwide (Cetin, 2015), which need to adapt their infrastructure and operations to changing demand, while at the same time complying with ever stricter environmental requirements (Lee, Chang, Lai, Lun, \& Cheng, 2018). Ports are thus introducing green programmes or green growth strategies to achieve a safe, efficient and environmentally sustainable port. This means that environmental issues arising from a port's construction and operation are no longer perceived as problems; instead, they are seen as opportunities (PIANC, 2014), and their solutions as a competitive factor of ports (Sislian, Jaegler, \& Cariou, 2016). Many ports have developed corporate social responsibility (CSR) strategies (Bergqvist \& Egels-Zandén, 2012) and environmental management systems (EMS), which include assessment procedures, internal policies and plans, as well as implementation actions (Coglianese \& Nash, 2001).

In making port activities greener, ports must (Puig, Wooldridge, Casal, \& Darbra, 2015): identify all port activities and their environmental aspects, create relationships between those two groups, define the criteria and establish a weighting system for the criteria, and finally create a connection between the environmental aspects of the port's activities and criteria. EMS thus requires science-based evidence on which to make decisions, the identification of key performance indicators (KPIs) by which to demonstrate achievements, and appropriate monitoring systems to assess both the efficacy of management and the quality of the environment itself (Wooldridge \& Stojanovic, 2004). Quantifications are thus essential, as they provide a baseline against which subsequent progress and performance can be measured (Merk, 2013).

Air emissions are just one of the negative impacts of port construction and operation that are addressed by the concept of green port growth. They are generally divided into two groups: the first relates to greenhouse gas emissions that cause climate changes, and the second to local pollutant emissions that affect human health and the environment. The first occur mainly as a result of ships sailing, and therefore are not the subject of this paper; while the latter are even more important if the port is located near urban areas, which is often the case.

Many port and port-related activities cause air emissions and a deterioration of air quality in the port's surroundings; sources of air emissions from ports can be divided into stationary (such as manufacturing facilities, electrical grid, warehouses, offices, etc) and mobile (such as vessels, cargo-handling equipment, heavy and light-duty vehicles, etc). The problem can be tackled in several ways, including changes in equipment and energy use, as well as changes at the operational level.
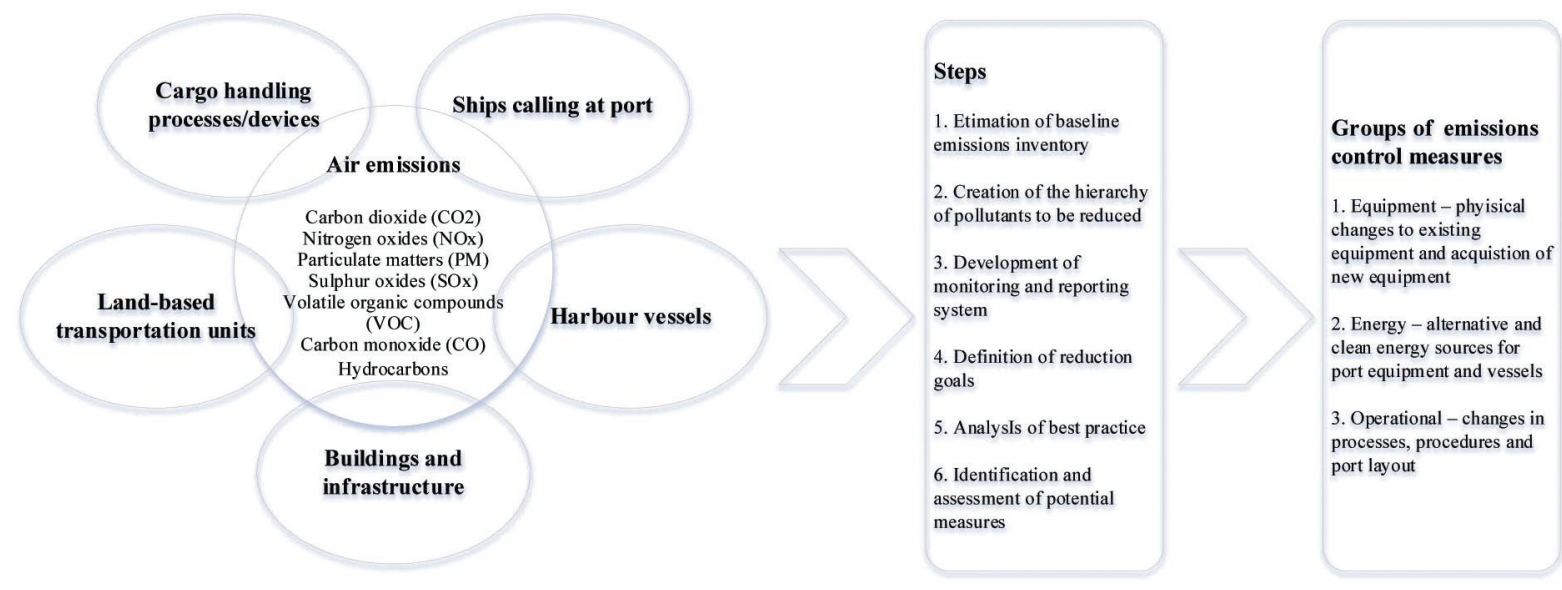

Figure 1. The sources and elements of port air emissions, and air emission reduction measures in ports

Source: Zanne, Twrdy (202x). 
The implementation of certain sustainability measures may increase initial costs, but usually such measures lead to life-cycle savings (Abood, 2007). Investment must be well thought out and justified. The EU proposes the use of cost-benefit analysis (CBA) in project selection, the results of which are usually expressed as a payback period (PP), where the disadvantage is the fact that the monetary value is not taken into account. This can be avoided by calculating the net present value, which relies on predicted future economic developments, and should be done with a certain reserve. It can be a problem, especially for projects that have a long service life (such as port cranes and other cargo handling equipment).

Another way to value investment is by using cost-effectiveness analysis (CEA), which is particularly useful when the benefits cannot be expressed in monetary terms. Compared to CBA, calculating CEA is simpler, but the CEA does not provide a comparison between activities that produce different outcomes. The results of CEA are expressed as ratios, namely the cost-effectiveness ratio (CER), or incremental costeffectiveness ratio (ICER).

\section{Data and methods}

We selected similar-sized European ports in terms of their total throughput, and analysed their environmental attitude. We focused on the Port of Koper, where we were able to conduct interviews and field studies, while for other ports we only reviewed available documents.

Although the case study method can be considered controversial, especially when it comes to an analysis of a single case, as it is unable to provide generalised assumptions (in terms of statistical generalisation), it is commonly accepted in the social sciences. In fact, case study research can be used to generate or test a theory with real case examples.

The research question was formulated at the beginning of the study. The main research question was: 'What air pollution reduction measures are applicable in small and medium-sized ports (SMPs), and how efficient can these measures be?'

\section{Air emission mitigation measures in smaller ports}

There are around 1,200 ports in the EU, of which the top three, Rotterdam, Antwerp and Hamburg, handle around one fifth of all goods arriving in Europe by sea, and the top 20 handle almost half of these goods (Eurostat, 2020). We all know about the largest European ports; however, there is no unique or absolute definition of what a large, medium or small port is. In the ESPO report (Verhoven, 2010), small port authorities are defined as those that in all managed ports handle less than ten million tonnes of cargo. Medium port authorities handle from ten to 50 million tonnes of cargo, while large port authorities handle more than 50 million tonnes of cargo. Feng and Notteboom suggest that considering throughput alone is not enough, and they proposed first seven (2011), later reduced to five (2013), dimensions to check when defining ports by size. But for this paper, the exact definition is not so important. We are dealing with environmental management in SMPs, and not in the largest European ports.

Small ports usually have a lower turnover per employee, a lower EBIT and EBITDA per employee, a lower return on assets, higher operating costs, and higher capital costs than bigger ports. Also, they receive lower revenues, and consequently have fewer resources for research and development and the investment associated with the improvement of the port's sustainability. Kuznetsov and others (2015) claim that proper sustainability management is thus rarely found in smaller ports; however, the ports that we have analysed suggest otherwise. 
Table 1. Main port describers: a comparison of SMPs and large ports in 2018.

\begin{tabular}{|l|l|l|l|}
\hline & Small or medium-size port (Koper) & Small or medium-size port (Tallinn) & Large port (Rotterdam) \\
\hline Throughput & 24 million tonnes & 20.6 million tonnes & 469 million tons \\
\hline TEU & 988,499 & 223,000 & 14.5 million \\
\hline EBIT & EUR 69.7 million & EUR 52 million (PA) & EUR 254.1 million (PA) \\
\hline EBITDA & EUR 99.1 million & EUR 74.4 million (PA) & EUR 439 million (PA) \\
\hline Revenue & EUR 226 million & EUR 130.6 million (PA) & EUR 707.2 million (PA) \\
\hline Employees & 1,242 & 496 & 385,000 \\
\hline Added value & EUR 162.5 million & & EUR 45.6 billion \\
\hline Calls & 1,903 & 1,754 & 29,476 \\
\hline Investment & EUR 15.8 million & EUR 14.3 million (PA) & EUR 408.1 million (PA) \\
\hline Land area & 274 ha & & 7,903 ha \\
\hline Water area & 179 ha & & 4,810 ha \\
\hline Assets & EUR 572.2 million & EUR 623.6 million & EUR 5.4 billion \\
\hline
\end{tabular}

Note: Luka Koper is a port manager and operator in the Port of Koper; the Port of Tallinn consists of five constituent harbours, and is organised as a landlord port; the Port of Rotterdam is also organised as a landlord port, thus it has a Port Authority and many different terminal operators (the financial data refers to Port Authority alone).

Source: (Luka Koper, 2019), (Tallinna Sadam, 2019), (Port of Rotterdam Authority, 2019)

The ports that we analysed are designed and operated according to sustainable principles. For example, Luka Koper obtained ISO 14001, the international quality and environmental management standard, in 2000 (Luka Koper, 2020), the Port of Tallinn in 2003 (Tallinna Sadam, 2019), and the Port of Taranto in 2012 (Porto di Taranto, 2012). Luka Koper received ISO 50001:2018, the energy management certificate, in 2020.

\subsection{Equipment measures}

Rubber-tyred gantry cranes (RTGs) are the biggest consumers of diesel fuel, and the biggest contributors to air emissions in ports. On average, one RTG consumes around 12 litres of diesel per hour, and they normally operate almost 24/7, more than any other equipment (for comparison, ship to shore (STS) container cranes in the Port of Koper operate on average nine hours per day). Therefore, the electrification of RTGs may be considered one of the strategic projects in ports. At Koper, almost one quarter of the container terminal equipment is electrified.

The price of an e-RTG is higher than that of a similar diesel-powered RTG; however, the estimated direct savings are EUR 60,000 per year per e-RTG compared to diesel-powered RTGs (interview in Luka Koper). Besides, an e-RTG provides $95 \%$ savings in diesel consumption, a reduction of operating costs of up to $70 \%$, a reduction of maintenance costs of up to $70 \%$, and a significant reduction of greenhouse emissions (CO2 and NOx) and noise pollution (Naicker, 2015). Therefore, it is senseless to calculate only the payback period for this equipment, as the scope of the acquisition is much wider. In fact, at Koper the better structure of energy consumption and the higher throughput resulted in lower consumption and a lower carbon footprint per unit handled.

It also shows that replacing a piece of equipment with an electric one, instead of retrofitting existing equipment with, for example, a hybrid power pack, diesel fuel saver, cable reel system or conductor rail system, provides better results in ports where the diesel equipment is older.

The lighting of yards and warehouses accounts for a high share of the ports' electricity consumption. Installing a smart and efficient lighting system is an excellent way to reduce total electricity consumption, and consequently harmful emissions and light pollution. Efficient lamps, fittings and controls save money and improve working conditions (ESPO, 2013). Dolamič (2018) conducted a CBA for installing a new LED lighting system in several areas of the Port of Koper. All simulations predicted better working conditions and cost savings ranging from $65 \%$ to $80 \%$. 


\subsection{Energy measures}

Directive 2014/94/EU of the European Parliament and the Council of 22 October 2014 on the deployment of alternative fuel infrastructure requires a core network of refuelling points for liquefied natural gas (LNG) at maritime ports to be available at least by the end of 2025, not only for port equipment fuelling, but also for offering bunkers to ships calling at the port (Off. J. of the EU, L 307/1, 2014). Besides economics benefits, the use of LNG also brings many environmental benefits, like a reduction of $\mathrm{SO} 2$ emissions of almost $100 \%$, and the reduction of $\mathrm{CO} 2$ emissions by more than $25 \%$ in comparison with diesel-powered equipment. Besides, emissions of particles and NOx also decrease.

A study of the gradual introduction of LNG vehicles at terminals in the Port of Koper was conducted in 2016. It envisaged the purchase of 95 terminal vehicles and handling equipment by 2030. The project is currently pending, because the Port of Koper is not connected to a gas pipeline, so it would be necessary to use trucks or boats, which would increase operating costs. However, as LNG is gaining in importance as a green ship bunkering solution, not only for merchant ships but also for tugs, it will probably become necessary to install an LNG station at Koper over time.

On the other hand, the Supervisory Board of the Port of Tallinn approved the construction of an LNG bunkering terminal in the port area in 2015. Only a few ports in the region offer possibilities for bunkering LNG, and this provides a competitive advantage to the Estonian port (Port of Tallinn, 2015).

The Port of Koper is located in part of the Adriatic where waves and tides are not enough to generate energy. Wind conditions are also unfavourable, but the region has a lot of sun, and they plan to install solar panels in the Port of Koper on the roofs of buildings and above open parking lots with a total area of almost 800,000 square miles. The first project is economically feasible, with a payback period of ten to 13 years; while the second one is more demanding, and would require a longer payback period (the estimated value of the project would be around 155 million EUR, calculation based on Tavčar, 2019). If ever constructed, the solar power plants would make the Port of Koper self-sufficient in energy, even if an on-shore-power supply (OPS) is installed.

The first offshore wind farm in the Mediterranean Sea will be in the Port of Taranto (PortsEurope, 2019). The farm will consist of ten wind turbines for the 30MW project.

While there is currently no reasonable justification for the construction of OPS at Koper (an estimated 60 million EUR investment), as mainly cargo ships call at the port, and they are not equipped with an adequate system, there is one already installed in the cruise terminal in the Port of Tallinn. The 3.5 million EUR investment allows shore supply from five piers. Five cruise ships operating Estonian-Swedish and Estonian-Finnish routes are currently properly equipped to connect to the OPS. In the coming years, the same company plans to equip a total of 12 cruise ships with shore power systems, amounting to six million EUR in total (Port of Tallinn, 2020). OPS reduces emissions and noise, as auxiliary engines do not need to run any more during the stay in port. Ships have different engine configurations; however, two or three auxiliary engines are usually installed on diesel-mechanical vessels, and four to six auxiliary engines on diesel-electric vessels (GLMEEP, 2016). For example, a rather small container ship with a capacity of around 4,000 TEUs has three auxiliary engines, each with $2,320 \mathrm{~kW}$ power, and each consuming 4.5 tonnes of fuel per day while in port. From the beginning of 2020, the sulphur content in marine fuel cannot exceed $0.5 \%$, but still, one tonne of marine bunker produces on average 3.17 tonnes of $\mathrm{CO} 2$ (independently of fuel type or engine type), $0.02 \times \mathrm{S}$ tonnes of SO2, and 0.057-0.087 tonnes of NOx depending on the ship's engine (Psaraftis, 2008).

\subsection{Operational measures}

A relatively inexpensive measure that can reduce energy consumption, and consequently emissions, while still maintaining operational efficiency, is eco-driving and the optimised routing of terminal equipment. Studies show that eco-driving can reduce fuel consumption by $10 \%$ to $15 \%$ a year on average (Kristensen, 2009). Also, the use of upgraded equipment can help in reducing costs; double-trailers that operate on the container depot in Koper reduce fuel consumption by $50 \%$. 
A scheduling system for arrivals of trucks can also be efficient. This is known as a truck appointment system (TAS) or vehicle booking system (VBS), and can, besides other things, result in a better utilisation rate of the terminals. It is especially beneficial when used to reduce the staying time of reefer containers in ports, as they are huge energy consumers. Luka Koper completed the VBS in November 2019, so the results cannot be assessed yet (Zanne \& Twrdy, 202x).

The global trend is to charge lower port fees for ships with engines that are more efficient. Rebates can range from $0.5 \%$ to $20 \%$ (EC, 2017). While the implementation of this measure can improve the image of the port, its value is broader, as it can help incentivise the more sustainable development of ships by supporting the adoption of cleaner fuels in maritime transport. Luka Koper is currently introducing emission ship index (ESI) port fees, while the Port of Tallinn has offered up to an $8 \%$ discount for environmentally friendly ships since the beginning of 2019 (Mfame, 2018).

\section{Discussion and conclusions}

The ports that we analysed are in different countries and are organised in different ways. The Port of Koper has a unique managing system, whereby the joint capital company Luka Koper acts as the port authority and the concessionaire in the port; while all the other investigated ports are landlord ports. All of them have a yearly throughput of around 20 million tonnes of cargo, and, like larger ports, they feel the environmental pressures in recent years.

Ports are a significant cause of air pollution around coastal areas, which can have serious health (see e.g. Corbett et al., 2007) and environmental impacts. All the analysed ports/port authorities are committed to operating in an environmentally friendly way, and to promote the efficient use of energy and other natural resources. Their operations comply with national, EU, ESPO and international environmental legislation and guidelines.

The managing structure of the Port of Koper allows Luka Koper to obtain a broader picture, and to implement an environmental protection system in all terminals and for all its activities. The landlord ports expect port operators to act in line with the environmental standards set by the port authorities. Ports are well aware of the importance of public opinion and the public perception of the port, and want to include public opinion in their decision making process.

Technology is highly important for the development of ports; but the implementation of some measures can be hindered because of the limited availability of financial resources, while some others can be determined by the location and natural conditions. Smaller ports have lower budgets or lower capital attractiveness, and thus less room for error; therefore, the measures must be evaluated well, with economic logic and efficiency still being the prevailing criteria; but environmental performance cannot and is not neglected, even in smaller ports. These ports should create a list of priorities, and, whenever possible, apply for European funding.

\section{References}

Abood, K. (2007). Sustainable and green ports: Application of sustainability principles to port development and operation. 11th Triennial International Conference on Ports, p. 1-10.

Bergqvist, R., Egels-Zandén, N. (2012). Green port dues - the case of hinterland transport. Research in Transportation Business \& Management, Vol. 5, p. 85-91.

Cetin, C. K. (2015). Port and logistics chains: Changes in organizational effectiveness. In D. W. Song, P. M. Panayides (eds.). Maritime logistics: A guide to contemporary shipping and port management. $2 \mathrm{nd}$ ed. London, Philadelphia, New Delhi: Kogan Page, p. 343-379.

Coglianese, C., Nash, J. (2001). Bolstering private-sector environmental management. Issues in Science and Technology, Vol. 17(3).

Corbett, J. J., Winebrake, J. J., Green, E. H., Kasibhatla, P., Eyring, V., Lauer, A. (2007). Mortality from ship emissions: a global assessment. Environmental Science Technology, Vol. 41, p. 8513-8518.

Dolamič, A. (2018). Ekonomski vidik izboljšanja okoljske učinkovitosti delovanja pristanišč / The eonomic aspect of enevironmental performance improvement in ports (unofficial translation). Portoroz: Faculty of Maritime Studies and Transport (diploma thesis). 
EC. (2015, January). Ports. Retrieved August 2020, from Mobility and transport: Source: Zanne, Twrdy (202x). Available on line: https://ec.europa.eu/transport/modes/maritime/ports/ports_es

EC. (2017). Study on differentiated port infrastructure charges to promote environmentally friendly maritime transport activities and sustainable transportation. Brussels: European Commission.

Eurostat. (2020, February). Top 20 ports - gross weight of goods handled in each port, by direction. Retrieved August 2020, from Eurostat: https://appsso.eurostat.ec.europa.eu/nui/show.do?dataset=mar_mg_aa_pwhd\&lang=en

Feng, L., Notteboom, T. (2011). Small and Medium-Sized Ports (SMPs) in Multi-Port Gateway Regions: the Role of Yingkou in the Logistics System of the Bohai Sea. Current Issues in Shipping, Ports and Logistics. ASP: Brussels, p. 543-563.

Feng, L., Notteboom, T. (2013). Peripheral challenge by small and medium sized ports (SMPs) in multi-port gateway regions: The case study of northeast of China. Polish Maritime Research, Vol. 20, p. 55-66.

GLMEEP. (2016). Improved auxiliary engine load. Retrieved January 2020, from Global maritime energy efficiency partnerships: https://glomeep.imo.org/technology/improved-auxiliary-engine-load/

HM Treasury. (2018). The green book: Central government guidance on appraisal and evaluation. London: Crown.

Kristensen, B. (2009). ECO Driving benefits the environment and saves money for the Port of Copenhagen. Retrieved December 2019, from Copenhagen Malmo port: http:/www1.cmport.com/en/news-and-media/news/2009/2009-12-01

Kuznetsov, A., Dinwoodie, J., Gibbs, D., Sansom, M., Knowles, H. (2015). Towards a sustainability management system for smaller ports. Marine Policy, Vol. 54, p. 59-68.

Lee, P. T. W., Chang, Y. T., Lai, K. H., Lun, V. Y., Cheng, T. C. (eds.). (2018). Green shipping practices and firm performance. The flagship journal of international shipping and port research, Vol. 61(B), p. 231-233.

Luka Koper. (2019). Letno poročilo 2018. Koper: Luka Koper (report of port).

Luka Koper. (2020). Sistem vodenja v Luki Koper, $d$. d. Retrieved September 2020, from Kakovost: https://luka-kp.si/ slo/kakovost

Merk, O. (2013). The competitiveness of global port-cities: Synthesis report. Paris: Organisation for Economic Cooperation and development.

Mfame. (2018, December). 8\% discount on tonnage fees for ESI ships in the port of Tallinn. Retrieved September 2020 , from Mfame: https://mfame.guru/8-discount-on-tonnage-fees-for-esi-ships-in-the-port-of-tallinn/

Naicker, R. (2015). Analysis of electric-rubber tyred gantries for a more green Durban Container terminal. IOSR Journal of Engineering, Vol. 5(6), p. 24-28.

PIANC. (2014). Sustainable port: A guide for port authorities. Brussels: The World Association for Waterborne Transport Infrastructure.

Port of Rotterdam Authority. (2019). Room for today and tomorrow. Make it happen. Rotterdam: Port of Rotterdam Authority.

Port of Tallinn. (2015, June). The Supervisiory Board of Port of Tallinn approved the construction of LNG terminal. Retrieved September 2020, from Port of Tallinn: https://www.tallinnlng.com/the-supervisiory-board-of-port-oftallinn-approved-the-construction-of-lng-terminal/

Port of Tallinn. (2020, September). The shore power solution launched today improves air quality and reduces noise in Old City Harbour and City of Tallinn. Retrieved September 2020, from Port of Tallinn: https://www.ts.ee/en/the-shore-powersolution-launched-today-improves-air-quality-and-reduces-noise-in-old-city-harbour-and-city-of-tallinn/

Porto di Taranto. (2012). Environmental Certification. Retrieved August 2020, from Autorità di Sistema Portuale del Mar Ionio - Porto di Taranto: https://www.port.taranto.it/index.php/en/environment

Ports Europe. (2019, March). Aizea Wind to build monopiles of the first Italian wind farm, located at Taranto port. Retrieved September 2020, from PortsEurope: https://www.portseurope.com/haizea-wind-to-build-monopiles-ofthe-first-italian-wind-farm-located-at-taranto-port/

Psaraftis, H. N. (2008). Logistics-emissions tradeoffs in maritime transport. Augsburg: OR.

Puig, M., Wooldridge, C., Casal, J., Darbra, R. M. (2015). Tool for the identification and assessment of environmental aspects in ports (TEAP). Ocean \& Coastal Management, Vol. 113, p. 817.

Sislian, L., Jaegler, A., Cariou, P. (2016). A literature review on port sustainability and ocean's carrier network problem. Research in Transportation Business \& Management, Vol. 19, p. 19-26.

Tallinna Sadam. (2019). Group annual report 2018. Tallinn: Tallinna Sadam.

Tavčar, B. (2019, September 19). Sonce bi lahko izkoriščali precej bolje / The sun could be exploited more efficiently (unofficial translation). Delo, p. 1-2.

Tongzon, J. (2002). Port choice determinants in a competitive environment. International Association of Maritime Economists - IAME. Panama.

UNCTAD. (2019). Review of maritime transport 2019. Geneva: United Nations.

Verhoven, P. (2010). The ESPO fact finding report: European port governance. Brussels: European Sea Ports Organisation.

Wooldridge, C., Stojanovic, T. (2004). Integrated environmental management of ports and harbours. In D. Pinder, B. Slack (eds.). Shipping and ports in the twenty-first century - Globalisation, technological change and the environment. London \& New York. 
Wu, J. (2011). The development of port and the container transport chain - a case study of Tianjin Port (master thesis).

Zanne M., Twrdy E. (2020). The economic feasibility of port air emissions reduction measures: The dy of the Port of Koper. Economic and Business Review.

Zhao, Q., Xu, H., Wall, R. S., Stavropoulos, S. (2017). Building a bridge between port and city: Improving the urban competitiveness of port cities. Journal of Transport Geography, Vol. 59, p. 120-133.

\title{
ORO TARŠOS MAŽUOSE UOSTUOSE ŠVELNINIMO PRIEMONIŲ EKONOMINË ANALIZE
}

\author{
Marina ZANNe, ELEN TWRDY \\ Liublianos universitetas (Slovėnija)
}

\section{Santrauka}

Kasmet pasaulio uostuose tvarkomi, sandèliuojami ir perdirbami didžiuliai krovinių kiekiai. Akivaizdu, kad uostai vaidina svarbų vaidmenị plètojant ekonomiką visame pasaulyje. Tačiau uosto operacijos tiek jūroje, tiek sausumoje turi neigiamų padarinių, kurie šiuolaikinèje aplinkai jautrioje visuomenèje tampa vis didesne problema. Todèl uosto administracija ir operatoriai turi ieškoti sprendimų, kaip šị neigiamą poveikị mažinti, išlaikant ar net didinant uosto konkurencingumą. Užduotis nelengva, nes uostai vienas nuo kito skiriasi daugeliu veiksnių, taip pat ir galimybe igyvendinti tam tikrus sprendimus ar pasirinktų sprendimų efektyvumu. Šiame straipsnyje autoriai daugiausia dėmesio skiria uosto operacijų metu išmetamo taršaus oro kiekiui. Jie nagrinėja visus uosto taršos šaltinius ir patikrina mažesnių krovinių uostų pasirinktų išmetamų teršalų kiekio mažinimo priemonių veiksmingumą. Pasirinktų priemonių veiksmingumo pavyzdžiai pateikiami iš Koperio uosto - vienintelio Slovėnijos krovinių uosto, esančio Šiaurès Adrijos jūroje, kurio krova 2019 m. sudarè 23 mln. tonų.

Pagrindinis tyrimo klausimas, kokios oro taršos mažinimo priemonės taikomos mažame ar vidutiniame uoste ir kiek tokios priemonės gali būti veiksmingos? Siekdami atsakyti ị iškeltą klausimą autoriai nustatė neigiamai aplinką uostuose veikiančius šaltinius, daugiausia dėmesio skyrè oro kokybės prastejjimui dẻl uostų veiklos. Pasitelkus atvejų analizę tirta, kaip šios problemos sprendžiamos pasirinktuose mažesniuose ir finansiškai silpnesniuose Europos krovinių uostuose.

Daromos išvados, kad spręsdami plètros ir oro taršos klausimus uostai siekia ịtraukti visuomenę ị uosto plètros sprendimų prièmimą. Be to, uostų plètrai ypač svarbios technologijos, vis dèlto ịgyvendinti kai kurias oro taršos mažinimo priemones trukdo finansinių išteklių prieinamumo stoka, kartais tai nulemta vietos ir gamtinių sąlygų. Mažesnių uostų mažesnis biudžetas, kapitalo patrauklumas, taigi mažiau toleruojamos ir galimos klaidos. Todẻl taršos mažinimo priemonès turètų būti vertinamos, remiantis ekonominės logikos ir efektyvumo kriterijais, aplinkosaugos neignoruojant net ir mažesniuose uostuose. Pastariesiems rekomenduojama parengti prioritetų sąrašą ir esant galimybėms siekti finansinès paramos iš Europos fondų.

PAGRINDINIAI ŽODŽIAI: uosto tarša, oro tarša, švelninimo priemonès, maži uostai, sąnaudu ir naudos analize.

JEL KLASIFIKACIJA: R42, R11, O18.

Received: 2020-10-20

Revised: 2020-12-15

Accepted: 2020-01-15 